\title{
Evaluation of Professional Accountancy Education and Training in Nigeria
}

\author{
Dr. Augustine Oke Okolie ${ }^{1}$, Prof. Famous O. I. Izedonmi ${ }^{2}$ \\ ${ }^{1}$ Department of Accounting, Ambrose Alli University, Ekpoma, Nigeria, \\ ${ }^{2}$ Department of Accounting, University of Benin, Benin City, Nigeria,
}

\begin{abstract}
This paper critically appraises the adequacy of the level and substance of the education and training that are required to prepare and equip the professional accountants to deal with the changing demands of the dynamic business environment in Nigeria. The methodology involved the use of library research and a review of available documentary evidences on the subject matter. The paper points out the previous constraints to professional accountancy training and development; the need for continuous professional education and training of professional accountants; the International Educational Standards for Professional Accountants; and the panacea for professional accountancy education and training in Nigeria. The strong point of recommendation is that professional bodies in Nigeria should pool resources together to establish a centre for accounting education and development that is charged with the responsibility to review and assess the current strengths and resource challenges of the various individual professional bodies and to jointly observe an intensive program of action that will minimize the challenges.
\end{abstract}

Keywords: Accountancy, Education, Profession, Standards, Training.

\section{Introduction}

The accountancy profession in Nigeria led by the Institute of Chartered Accountants of Nigeria (ICAN) is a citadel of scholarship and academic excellence which determines and maintains very high standards of knowledge and skill for the members of the accountancy profession resulting in the production of high level manpower, men and women of excellent qualities, who are the kingpins in the management of the financial institutions and business organizations in the Nigerian economic landscape.

Whereas the Association of National Accountants (ANAN) has a School of Accountancy located in Jos, Nigeria for training professional members of ANAN, several questions have been raised on why the ICAN has refused to establish a school of accountancy. The answer, according to Ojaide is quite simple and straight forward:

1. The country has several Polytechnics and Universities offering accountancy courses,

2. There are also several private tuition houses preparing students for professional accountancy examinations,

3. The Institute of Chartered Accountants of Nigeria has also accredited the Federal Treasury Training School for the Civil Service and the Nigeria Army School of Finance and Administration as recognized training institutions for the training of accountants in the public sector.

With the existence of these institutions of learning, it will be appreciated that any attempt to establish a theoretically based school of accountancy will be tantamount to duplication and a waste of scarce resources. ICAN is expected to promote the integration of theoretical knowledge acquired in the classrooms with the practical aspects necessary to make a Chartered Accountant quite functional, both to himself and to the society [1]. It has been argued that at the outset of existence, almost all the learned professions required no formal education. Various forms of apprenticeship or 'articleship' were employed to prepare candidates for various professions. However, as the professions matured and the knowledge required for competent practice grew, the professions adopted formal requirements for formal education [2]. Currently, professions such as medicine, law, engineering and architecture require five or more years of university and other higher education. Professional accounting in Africa lags behind other professions in the continent and the accounting profession in other parts of the World is not explicitly requiring at least a baccalaureate university education as an entry requirement.

Formerly, accountants have been overwhelmed by an increase in the subject matter of what has had to be integrated into the accounting curriculum. The continuous increase in authoritative pronouncements concerning principles and standards of accounting and auditing alone represent a significant increase in relevant curriculum material. Equally, dramatic developments have occurred in a number of supporting disciplines such as computers and information systems, economics, quantitative analysis, behavioral sciences, tax laws and their revisions. Personnel needs of accounting firms and practice have changed substantially in recent years. Advances in technology, for example, have resulted in a drastic reduction in the large number of clerical staff hitherto required to perform routine tasks in auditing. 
Collectively, the magnitude of these developments in the boundaries of accounting practice, and content of accounting curriculum, raises serious challenges to the adequacy of current entry level qualifications to professional accountancy and the competing claim of accountancy in Nigeria in particular. Also, these developments raise significant questions about:

1. Whether those entering the accountancy profession in Nigeria have been educated to an internationally minimum acceptable level, and

2. Whether the entry level qualifications can sustain them for a lifelong career in the accountancy profession.

The question is whether the profession can find replacement for the older generation of accountants who have been able to keep the flag of the profession flying up to this present stage? Certainly, aging is a process of progressive deterioration of the adult and is correlated with the passage of time. Thus, as a human being grows older, there is progressive reduction in stamina, ability to perform maximally in tasks requiring coordination of movements, vision, hearing, and in functions of various organs, including the brain, heart, kidneys and the liver.

It is unacceptable for the profession to accept men and women who have not undergone the necessary professional training in accountancy into direct membership based on the arguments that they have acquired several years of experience on the job without passing the various stages of the required professional examinations. Such individuals are expected to follow the processes of writing the required professional examinations in order to qualify as Chartered Accountants [1].

The field of Accounting is highly dynamic and in the business environment, the contemporary role of accountants has presently shifted from accounting processes to decision support, business strategies, strategic framework and balanced scorecard involving both financial and non-financial performance measures, risk management and corporate governance, and a culture of prospecting into the future. Thus, there is a move towards a multi - dimensional approach. The choice of expertise necessary for performing the increasing, plenty and varying responsibilities of accountants comprise technological capabilities in the critical professional spheres of accounting, auditing, taxation, finance, business strategy, Information technology, social skills, ethical skills, communication skills, managerial skills, Leadership skills; etc.

The professional accountancy bodies have constantly acknowledged the following vital mechanism for active accountancy and audit practice, inter alia: Integrity, Objectivity, Independence, Skill, diligence and due care. At the moment, there is an emergent promotion and advocacy for significant ethical skills resulting from the recent numerous corporate scandals and corporate disintegration across the world even as there are more instances of financial scams perpetrated in Nigeria than is openly admitted [3]. These recent corporate financial scandals pose a great challenge to the veracity, credibility, utility or value relevance to the accountancy function [4]. There are quite a lot of companies reported to have been involved in cases of accounting scandals related to poor financial reporting quality and earnings manipulations in the past decade [5]. In Nigeria, corporate scandals include the cases of Cadbury Nigeria Plc and African Petroleum (AP) [6], Savannah Bank and African International Bank [7]; Wema Bank, Nampak, Finbank and Spring Bank [8]; and more recently Intercontinental Bank Plc., Bank PHB; Oceanic Bank Plc. and AfriBank Plc [4].

Educators say that human development efforts typically focus on education, skills and attitudes. Essentially, the pertinent issues include determining the best way to educate the present and future accountants; the requisite skills to inculcate in the potential collection of Accountants; and how the accountant can imbibe the correct attitudes that will boost the standing image of the profession. The three developmental traits overlap and interface with one another [3].

\subsection{Problem Analyses}

Although the accountant in practice is hired and paid by a client, he actually serves public interest. Public interest is the collective well-being of all those who rely on his reports for various kinds of decisions. It has been suggested in some circles that when the auditor, in the course of his work, ignores the fact that he serves public interest, he ceases to be a professional but descends to the level of a tradesman [9].

There is no gainsaying that as individuals are passing through very difficult times in the history of Nigeria, the country itself is also going through a very traumatic experience in her economic and social well being. Whatever the direction, Nigeria remains faced with a general economic depression which requires quality personnel with sound intellectual and professional competence and capacity to manage. In the attempt to meet the astounding future challenges, the accountant is expected to prepare, train and re-train so that he can adequately handle the changing circumstances in order to assist and advise government, clients and the general public.

It has been argued that the management of financial resources in the Nigerian public sector has suffered from a myopic and constricted perception of what was actually involved in it. The problem practically appears to be essentially the inability to understand its character, function and procedures. Furthermore, other issues relate to the organizational structure and the training and qualifications of financial personnel. Similarly, the 
multi - dimensional approach presents a study body with varied backgrounds in disciplines like Agriculture, Chemistry, Pharmacy, Philosophy, Political Science, Sociology, Engineering, etc, aspiring to qualify as chartered accountants. With this trend, ICAN assures Nigeria of high caliber and unbeatable professional accountancy being nurtured for the future of Nigeria. In view of the developments, the accountant in education was expected to have satisfactory and sufficient educational background to assist government in policy formulation and execution rather than sheer conventional accounting functions that seemingly engross the professional accountant for the most of the time.

University accounting programmes in Nigeria seem to have been too narrow, too technical and too closely modeled after the professional certificate. They seem to be perfect clones of ICAN syllabus, instead of giving the students broad and flexible foundations. They do not encourage original thinking and initiative. Such system can only produce accountants who are only simply number crunchers. They may end up being at best simply as Chief Accountants but never business leaders or CEO.

Presently, the Nigerian Universities and educational system grossly discriminate against non - graduate professional accountants in their employment policies, either as lecturers (part-time or full-time) or at top level administrative positions except such accountants possess higher degrees in addition to their professional qualifications. The grounds for this relegation are traceable to the fact that such professional accountants concentrate more on the pursuit of money than on policy recognition and/or they are alienated by their academic limitations. Thus, poor connection between professional accountants and academics has hindered the growth and advancement of accountancy education in Nigeria. Apart from the demand on skills, the accountants almost network with other professionals in the normal course of duty. Consequently, the multi - dimensional approach means that the accountant should be multi - skilled and an individual expert with various facets of specialist skills.

During the period of the International Monetary Fund (IMF), Loan and loan conditionality, and later the Second Tier Foreign Exchange Market (SFEM) and the Structural Adjustment Programme (SAP), accountants were not vehement in their contributions although they adapted somewhat swiftly to the concepts. Perhaps, this was in acknowledgement of their academic constraints in the education process or a sub conscious desire to stay aside and watch the academics and the few academically inclined professional accountants.

The increasing incidences of breach of professional ethics indicate the extent of digression of accounting firms from focus on pure auditing to business advisory services. Over time, the latter began to contribute a larger share of the firm's income. This diffusion enables persons who did not go through the rigor of audit apprenticeship, and who therefore did not have a firm grounding in professional ethics, to attain leadership positions in the audit firms [16]. If this theory is true, it raises a clear need or issue of whether audit firms should continuously seek ways to fill in relevant training gaps in their managerial personnel through formal education?

\subsection{Previous Constraints to Accountancy Training and Education in Nigeria}

Accountancy education curriculum in our Universities and Polytechnic often tends to be constricted, outdated and inappropriate. A research conducted among US Universities has affirmed that the programmes of study tend to be motivated by the interests of faculty and not by the market demands [10]. Other problems that have beset the accountancy profession include:

1. The academic content is often inadequate, deficient in creativity and consisting predominantly of lecture method. There is insufficient use of other educational methods such as discussion, group work, multi-media exposition, personal exploration and discovery, case study, etc.

2. Too much emphasis on "rule-based, memorization, test-for content, and preparation for the certifying examination" model. This fails to prepare the student for the uncertain business world that lie ahead their graduation,

3. Insufficient Information Technology (IT) in the curricula [11] and little or no integration of IT into the teaching of courses [12] with most of the teachers lacking IT competence,

4. Insufficient amount of "ethics" and "corporate governance" contents in the curricula,

5. Students are not sufficiently exposed to standard literature on the subject. The teachers' self authored "books" and mimeographs are often prescribed to the exclusion of authoritative texts. Often, these have not been subjected to peer review or a proper publishing regime,

6. There is little room for skill development in the absence (or a total lack) of industrial attachment built into the training scheme,

7. Inadequate student exposure to national or international standards to support the principles taught, hence, students are ignorant of current world trends,

8. Many staff members have no relevant practical exposures and cannot give appropriate examples to illustrate or support theory and principles, 
9. Many staff members do not belong to recognized professional bodies; thus have no access to professional journals, and hence they are hopelessly out of date!

10. Chronic disabilities on the part of small-time practitioners who lack the time and the means to pursue continuous self - development.

11. Insufficient or half - hearted enforcement of the Continuing Professional education (CPE) Programmes.

\section{Professional Accountancy Education/Training Need in Nigeria and the Theory of Inspired Confidence}

The move towards a multi - dimensional approach to professional practice requires a selection of requisite expertise for performing the growing and varied responsibilities of professional accountants, spanning technological capabilities in critical professional spheres of accounting, auditing, taxation, finance, business strategy, information technology, social skill, ethics, communication, managerial and leadership skills. Public expectations from the accounting profession have risen substantially with respect to the range and extent of responsibility accountants assume. This is evidenced in part by substantial litigations involving auditors, the spate and magnitude of fraud and embezzlement reported in the press, and the recurrent and increasing demand on public officers and politicians for accountability. This public expectation evokes the need and justification for the proper education and overall development of the professional accountant and is based on the Limperg Institute's theory of inspired confidence [13].

No single training approach can be best for all circumstances. Various topics, teaching methods and places affect each individual and circumstances differently. Some circumstances and people are best suited for reading or self-study, others are appropriate for seminars and workshops that present problems and case studies, while others are most appropriate for overseas stints or hands-on experience. The most commonly identified training options available to individuals and companies to include lecture discussions, Seminars, Correspondence courses, Self-study, Overseas stints, Study leave, Workshop, Work releases, Panel discussions, Group discussions, Practical exercises, Case studies, Simulations, Programmed instructions, Audio-visuals, Demonstrations, On-the-job-training, Conferences, Role playing, and Internship [2].

The choice of a training method is determined by the specific training needs and circumstances. The guiding principles for evaluating a training program are that the program should contribute to professional competence and career development of the participant and/or the employer. Thus, the major pre-condition to determining training programs and options is to make a thorough assessment of both the firm's and the individual's needs. The assessment of training needs involve determination of firm objectives, skills needed to perform the work of the firm, specific deficiencies of staff members, and aspiration goals of individuals.

Training flourishes in a supportive environment. The congenial environmental factors include top management commitment, challenging subject matter, communication with participants, competent instructors, and performance evaluation and career counseling.

The educational foundation that we ought to give would-be accountants in Universities needs to be broad-based and dynamic; incorporating a greater dose of theory and principles such as would make them versatile and adaptable to any of the numerous roles they may be called upon to play after graduation. There should be a greater differentiation between the University degree and the professional certificate. The Universities needs to concentrate on giving a sound broad educational foundation leaving the profession to examine for technical competence. Few of the products will be capable of making a success of higher academic work. This may largely be responsible for the bottom-heavy nature of the career structures that are found in most accounting departments of Universities in Nigeria. The tools which should facilitate research and originality, investigation and inventiveness are lacking in their basic preparations.

This accountant - public gap necessitate the proper education and overall development of the professional accountant supported by the Limperg Institute's theory of inspired confidence. The theory of inspired confidence offers a linkage between the users' requirement for credible and reliable financial reports and the capacity of the audit processes to meet those needs. It sees through the development of the needs of the public (stakeholders) and the audit processes over time [4]. Developed by the Limperg Institute in Netherlands in 1985, the theory of inspired confidence states that the auditor, as a confidential agent, derives his broad function in society from the need for expert and independent examination as well as the need for an expert and independent judgement supported by the examinations. Accountants and auditors are expected to know and realize that the public continues to expect a low rate of audit failures. This requires that the auditors must plan and perform their audit in a manner that will minimize the risk of undetected material misstatements. Thus, it has been asserted that the accountant is under a duty to conduct his work in a manner that does not betray the confidence which he commands before the rational person. On the other hand, the accountant may not produce what is greater than the expectation of the public [13]

The import of the theory of inspired confidence is that the duties and responsibilities of the accountants are a derivation from the confidence that are bestowed by the public on the success of the audit process and the 
assurance which the opinion of the accountant conveys. Since this confidence determines the existence of the process, a betrayal of the confidence logically means a termination of the process or function. Thus, when the confidence that society has in the effectiveness of the audit process and the audit report is misplaced, the value relevance of that audit is destroyed [14]. Therefore, accountants are expected to maintain reasonable quality assurance especially given that an audit failure is effectively a career-ending event. Audit provides assurance to the owners and management of companies and to investors and stakeholders, and along with financial reporting, corporate governance and regulations, supports confidence in the capital markets.

\subsection{International Education Standards for Professional Accountants}

In order to ameliorate the above short comings of accounting education in the contemporary word, the International Federation of Accountants (IFAC) developed new International Education Standards that will address pre-qualification education of professional accountants. This new standards are aimed at producing competent professional accountants worldwide since the global accounting profession is moving steadily towards a common base of standards in Accounting, Auditing, Public Sector Accounting and Ethics. IFAC member bodies were expected to comply with the standards by January 2005 [12].

The Introduction to International Education Standards for Professional Accountants provides background information about the purpose, scope and development of the International Education Standards for Professional Accountants in the areas of entry requirements for candidates beginning the qualifying process for becoming professional accountants; content of professional education programs for candidates required to qualify as processional accountants; professional skills and general education required for candidates to qualify as professional accountants; professional values and ethics that professional accountants need to acquire during their programmes of education and practical experience. The aim of this standard is to ensure that candidates for membership of an IFAC member body are equipped with the appropriate professional values and ethics to function as professional accountants as well as possess the practical experience and training IFAC member bodies require their members to obtain to qualify as professional accountants.

The aim of this standard is to ensure that candidates for members of an IFAC member body have acquired the practical experience considered appropriate at the time of qualification to function as competent professional accountants; assessment of professional competence of a candidate's professional competence before admission to the profession; and continuing professional education and development which requires that member bodies of IFAC establish a continuing professional education and development (CPED) requirement for all accountants. This is an important aspect of serving the public interest and fosters values of continuous learning and greater professional competence among professional accountants so as to better meet client and employer needs.

Apart from formal education at the University, Polytechnics and Colleges, members of the accountancy profession undertake further trainings through Continuous Professional Education (CPE), The Mandatory Continuing Professional Education (MCPE) and Executive Mandatory Continuing Professional Education (EMCPE). These are discussed briefly below:

\subsection{Continuing Professional Education (CPE)}

The CPE was designed to provide sound professional training to members and non-members on all subjects covering accounting, management, finance, taxation, banking, and more. The CPE has been in existence since the early 1970s but was stopped in 1995 for re-positioning but was re-introduced in year 2000 by the institute of Chartered Accountants of Nigeria. The CPE programmes cover numerous areas: (i) Current issues in retirement and pension planning; (ii) Corporate fraud prevention and detection (iii) Outsourcing as an efficient economic growth agent, (iv) e-commerce, (v) Human capital accounting, etc.

\subsection{The Mandatory Continuing Professional Education (MCPE)}

The MCPE is an all or every qualified member's programme of the Institute of Chartered Accountants of Nigeria whose membership is current. However, the following members of the institute may be exempted from the programme:

1. those who are 65 years old and above and who have indicated to the institute in writing their intention to retire from practicing the profession, and

2. all other members who are certified as medically unfit.

This programme was introduced into the accountancy profession in Nigeria in July 1996 as an improvement on the voluntary Continuing Professional Education (CPE) programme which the institute had successfully organised for many years to enrich the knowledge of members. The MPCE programme was a bold attempt by ICAN to assist and equip all Chartered Accountants with the requisite modern tools needed to keep abreast with and adapt to the enormous evolving changes, through continuous formal training and re-training.

Like other professional bodies in Nigeria MCPE is directed at: 
1. maintaining an adequate level of up-to-date technical knowledge among Chartered Accountants;

2. assist members of the profession to adapt to the evolution of new techniques, changing responsibilities and economic conditions nationally and internationally;

3. demonstrate the Institute's social responsiveness by encouraging members of the accounting profession to have adequate current technical knowledge and skill in the drive towards maintaining professional excellence at all times; and

4. maintain the competence and relevance of the Chartered Accountants in present socio - political and economic environments in the country.

By nature, the MCPE Programmes is designed to provide members with the necessary and up-to-date information about the Accountancy Profession, both nationally and internationally. While striving to bridge the gap between theoretical thoughts and the practice of accounting, the programme enhances members' knowledge and professional competence through structured course initiated, organized or approved by the institute for members in auditing/consulting; industry/commerce; public sector accounting; information technology. Therefore, in addition to formal lectures by erudite scholars in the academia, industry and the profession, group discussions and sharing of live experiences are greatly encouraged. The Faculty is advertised from time to time.

MCPE attendance in person and full participation in the following activities is compulsory for professional accountancy members:

(a) Structured/Organised Programmes,

(b) The Institute's Annual Budget Seminars,

(c) Approved relevant Seminars/Course organised by Professional firms of Chartered Accountants and Employers,

(d) Annual Conferences of the Institute, (e) Participation in some selected institute's activities,

(f) Attendance at courses organised by other recognized professional bodies and organisations locally or otherwise approved by the Institute.

In addition to the enrichment of knowledge and acquisition of new skills, every member whose records confirm attendance and participation in MCPE programmes up to the approved minimum credit hours, is considered eligible, apart from other laid down requirements, to:

(i) remain on the membership Register,

(ii) obtain a Practicing License,

(iii) renew a Practicing License,

(iv) apply for transfer to Fellowship,

(v) recommend/and endorse students' applications for registration, exemptions and/or examinations and induction programmes,

(vi) Obtain a member's practicing seal.

\subsection{Executive Mandatory Continuing Professional Education (EMCPE)}

The EMCPE was planned for members of the institute who occupy top positions in their organizations. The accountancy profession recognizes the very stretched schedule of this class of members and how that situation impacts negatively on their ability to attend the regular MCPE programmes and. Hence, the Executive MCPE was packaged to enable such top executives attend the seminars and workshops in most congenial setting and earn the required credit hours.

\section{Formal Education as Panacea for Professional Accountancy Training in Nigeria}

1. The Nigerian Universities, Polytechnics and Colleges should Strengthen education curricula to incorporate larger doses of its principles and ethics;

2. Totally abolish poorly authored texts from the class room. Accounting teachers should themselves observe the professional ethics of due care and diligence!

3. Accounting teachers should strengthen their own professional competence through belonging to a recognized professional accounting body, or at least subscribe to standard professional journals.

4. Provides a well-stocked and update libraries in institutions.

5. Accounting teachers should acquire some degree of professional teaching skill. Institutions should organize professional teaching workshop and seminars for their academic staff.

6. Accounting teachers should, as part of their self-development activities, explore opportunities to expose themselves through attachment/liaison to practicing audit firms or industrial/commercial organizations during vacations.

7. National and international standards should mainly form the basis of teaching Advanced Financial Accounting at the final year of degree/higher diploma.

8. The Professional Institute should strengthen its Research and Technical functions so as to give effective back-up to its members on a continuing basis. 
9. The Financial Reporting Council Nigerian (FRCN) should proceed to rapidly update its standard development programme or convergence with IFRS.

10. The Professional Institute should strengthen its disciplinary mechanism to sanction its erring members effectively and promptly.

11. It has been shown that creative accounting is a widespread practice in many countries, and that the cases that get exposed are only a tip of the iceberg [15]. There is evidently need to tighten prevailing regulatory mechanism, through the creation of oversight bodies such as Public Company Accounting Oversight Board (as in the USA) and the financial Reporting Council (as in the UK).

12. Finally, the professional Bodies should find a way to enforce their respective $\mathrm{CPE}$ and $\mathrm{MCPE}$ programmes more strictly.

\section{Conclusions and Recommendations}

The expanse body of knowledge and practice in the accounting profession has made continuing professional education for accountants mandatory in most parts of the developed world. Earning and retaining international professional recognition and reputation require that accounting bodies in Nigeria and Africa modify their education and training to conform to the generally accepted international standards. It also requires that organized continuous training programs be planned, developed and implemented by the professional bodies. Accounting education and tanning facilities in Nigeria are either largely inadequate or rudimentary. Accordingly, the focus of continuous training actions should be on how to improve or create local education/training facilities; encourage local professional accounting bodies to liaise with local universities/institutions and international professional bodies and institutions to plan, develop, and implement training programs that would:

(a) Encourage and assist aspiring accountants to qualify as accountants and advance in their career,

(b) Prevent qualified accountants from becoming professionally obsolete and/or incompetent,

(c) Encourage and assist accountants to keep abreast with accounting and auditing principles, standards and developments, and improve their public image locally and internationally, and

(d) Generally improve the quality of accounting education and practice in the continent.

Accordingly, it is recommended that all the accounting bodies pool their resources to establish a center for accounting education and development. The center would make an assessment of the current strength and challenges of available resources in individual bodies, and monitor a concerted program of action to alleviate the weakness. The suggestions are recommended for the improvement of the accountancy practice in Nigeria and the challenges that may face the accountant in the future.

The ICAN and other professional bodies in Nigeria should concentrate resources in the promotion of organized and problem -oriented research; establish and provide advanced research facilities for members. These facilities will in no small measure assist in providing urgent solutions and the much-needed base-line information for tackling fundamental problems of development, be it at the local, national or international levels.

The professional accounting bodies should liaise with Universities in the country to find out ways by which professional accountants who have no University degrees can as a matter of policy and understanding, be allowed to pursue one or two year remedial degree programmes in accounting and related disciplines. This will prepare them to pursue 'Masters' and 'Doctorate' degree to enable the accountants understand, imbibe and appreciate the different theoretical and empirical models which could be of vital tools.

As a follow-up to the above, the professional bodies should encourage its members notwithstanding age or sectors of their employment, to write academic and professional books; contribute to articles in national and international journals; participate actively in symposia and seminars at the national level, especially on topical issues affecting accountancy and other professions and those concerning the nation. The bodies should totally reject mediocrity and not accept substandard training and education used as a pretext of meeting the inadequacy of professional accountants in the country. There can be no replacement for professional excellence.

\section{References}

[1] Ojaide, F. (1991). Accountancy Education in the Next 10 Years; The Nigerian Accountant; Vol. XXIV, No. 3. Pp.10 - 13.

[2] Ghartey, J. B. (1993). Continuing Training Actions for Accountancy in Africa; The Nigerian Accountant; Vol.XXVI, No. 2, April/June, 1993. Pp. $38-41$.

[3] Anao, A.R. (1981) "The Training of Accountants for the Multi-Facets of Development", Paper Presented at the 1981 Conference of the Nigerian Accounting Teachers Association, Zaria.

[4] Okolie, A. O. (2013). Audit Quality, Earnings Management and Earnings Response Coefficients of Quoted Companies in Nigeria; Unpublished Ph. D Thesis, University of Benin, Benin City, Nigeria

[5] Badawi, I. M. (2008). Motives and consequences of fraudulent financial reporting. paper presented at the $17^{\text {th }}$ annual convention of the global awareness society international, May, 2008, San Fracisco, USA.

[6] Okolie, A. O. and Agboma, D. J. (2008). The impact of environmental dynamics on the accounting profession in Nigeria. Journal of Business Administration and Management., 3 (1), 70 - 75. 
[7] Odia, J. (2007). Creative accounting and its implications for financial reporting in Nigeria. Nigeria ournal of Business Administration, 8 (1 \& 2) (Jan/July).

[8] Adeyemi, S. B. and Fagbemi, T. O. (2010). Audit quality, corporate governance and firm characteristics in Nigeria, International Journal of Business and Management, 5 (5), $169-179$.

[9] Anao, A. R. (2009). A Critical Appraisal of the Teaching and Practice of Accounting in Nigeria; NASB Seminar for Lecturers of Accounting and Related Subjects on SASs, IFRSs and IPSASs; April 29th - 30 ${ }^{\text {th }}, 2009$ at Precious Palm Royal Hotel, Benin City.

[10] Albrecht, W.S. \& Sack, R.J. (2000), Accounting Education: Charting the Course through a Perilous Future, American Accounting Association).

[11] World Bank (2004) "Report on the Observance of Standards and Codes - Nigeria"

[12] IFAC (2006), "The Diverse Roles of professional Accountants in Business (Professional Accountants in Business Committee).

[13] Limperg Institute, (1985). The social responsibility of auditors: a basic theory on auditors function. The Limperg Institute, Netherlands.

[14] Carmichael, D. R. (2004). The PCAOB and the social responsibility of auditors, Accounting Hrrizons, 18 (2), 127 - 133.

[15] Inanga, E.L. \& Sen, D.P. (2009) "Creative Accounting: A Case Study and Global Dimension of the Phenomenon, ABWA Journal, Vol 1, no. 3

[16] Wyatt, A.R. (2003) “Accounting Professionalism - They Just Don’t Get It”, AAA Annual Meeting, Honolulu, Hawail.

\section{About the authors:}

${ }_{1}^{1}$ Augustine Okolie earned his doctor of Philosophy (Ph. D) in Accounting from the University of Benin, Benin City, Nigeria. Dr. Augustine Okolie is a Senior Lecturer in Accounting at Ambrose Alli University, Ekpoma, Nigeria. He is a fellow of the Institute of Chartered Accountants of Nigeria (FCA).

${ }^{2}$ Famous Izedonmi earned his doctor of Philosophy (Ph. D) in Business Administration from the University of Benin, Benin City, Nigeria $\mathrm{He}$ is a Professor of Accounting at the University of Benin, Benin City, Nigeria. Prof. Famous Izedonmi is a fellow of the Institute of Chartered Accountants of Nigeria (FCA). 